San Jose State University

SJSU ScholarWorks

Master's Theses

Master's Theses and Graduate Research

1996

\title{
Oncology nurses' attitudes toward the legalization of voluntary active euthanasia
}

Andrea Linder

San Jose State University

Follow this and additional works at: https://scholarworks.sjsu.edu/etd_theses

\section{Recommended Citation}

Linder, Andrea, "Oncology nurses' attitudes toward the legalization of voluntary active euthanasia" (1996). Master's Theses. 1238.

DOI: https://doi.org/10.31979/etd.fsdh-w4kh

https://scholarworks.sjsu.edu/etd_theses/1238

This Thesis is brought to you for free and open access by the Master's Theses and Graduate Research at SJSU ScholarWorks. It has been accepted for inclusion in Master's Theses by an authorized administrator of SJSU ScholarWorks. For more information, please contact scholarworks@sjsu.edu. 


\section{INFORMATION TO USERS}

This manuscript has been reproduced from the microfilm master. UMI films the text directly from the original or copy submitted. Thus, some thesis and dissertation copies are in typewriter face, while others may be from any type of computer printer.

The quality of this reproduction is dependent upon the quality of the copy submitted. Broken or indistinct print, colored or poor quality illustrations and photographs, print bleedthrough, substandard margins, and improper alignment can adversely affect reproduction.

In the unlikely event that the author did not send UMI a complete manuscript and there are missing pages, these will be roted. Also, if unauthorized copyright material had to be removed, a note will indicate the deletion.

Oversize materials (e.g., maps, drawings, charts) are reproduced by sectioning the original, beginning at the upper left-hand corner and continuing from left to right in equal sections with small overlaps. Each original is also photographed in one exposure and is included in reduced form at the back of the book.

Photographs included in the original manuscript have been reproduced xerographically in this copy. Higher quality $6 " \times$ 9" black and white photographic prints are available for any photographs or illustrations appearing in this copy for an additional charge. Contact UMI directly to order.

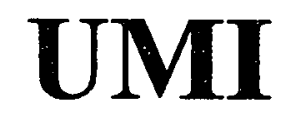

A Bell \& Howell Information Company 300 North Zeeb Road, Ann Arbor MI 48106-1346 USA

$313 / 761-4700 \quad 800 / 521-0600$ 


\section{ONCOLOGY NURSES' ATTITUDES TOWARD THE LEGALIZATION OF VOLUNTARY ACTIVE EUTHANASIA}

\section{Presented to}

The Faculty of the Division of Health Professions San Jose State University

In Partial Fulfillment

of the Requirements for the Degree

Master of Science

by

Andrea Linder

May, 1996 
UMI Number: 1379353

\section{Copyright 1996 by Linder, Andrea Lee}

All rights reserved.

UMI Microform 1379353

Copyright 1996, by UMI Company. All rights reserved.

This microform edition is protected against unauthorized copying under Title 17, United States Code.

\section{UMI \\ 300 North Zeeb Road \\ Ann Arbor, MI 48103}


() 1996

Andrea Linder

ALL RIGHTS RESERVED 
APPROVED FOR THE DIVISION OF HEALTH PROFESSIONS

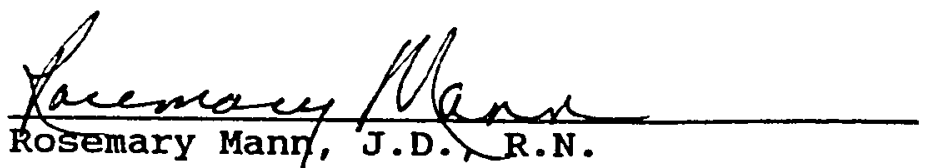

Rosemary Mann, J.D.入R.N.

Vigil Parsons

virgil Parsons, D.N.Sc., R.N.

Christine Hall ns, ex

Christine Hall, M.S.N., R.N.

APPROVED FOR THE UNIVERSITY

In Sou Lewandouthe 
ABSTRACT

ONCOLOGY NURSES' ATTITUDES TOWARD THE LEGALIZATION OF VOLUNTARY ACTIVE EUTHANASIA

by Andrea Linder

This study used a descriptive comparative design to explore oncology nurses' attitudes toward the legalization of voluntary active euthanasia. The study sample consisted of oncology nurses $(\underline{N}=262)$ who were randomly selected from the 1995 oncology Nurses Society membership list and who resided in the western states of Caiifornia, Oregon, and Washington. The study was a replication of Richardson's (1994) study that surveyed oncology nurses' attitudes in the midwestern states of Illinois, Indiana, Missouri, and Iowa.

Oncology nurses completed a 15-item questionnaire. A comparative analysis showed differences in attitudes between geographical regions. Findings indicated that nurses in the western U.S. were more likely than oncology nurses in the midwest to agree that patients should have the legal option to end their own lives, and that patients should have assistance from healthcare workers to end their lives. Attitudes of oncology nurses in the west were less likely to be influenced by religion than in the midwest. 


\section{ACKNOWLEDGEMENTS}

I wish to thank my wonderful husband steve and sons Simon and David for all their patience and support throughout this project. I also want to thank my friends Linda and sue who always kept me focused with their continued encouragement to make my dream a reality. 
TABLE OF CONTENTS

Page

LIST OF TABLES ....................... viii

Chapter

1. INTRODUCTION $\ldots \ldots \ldots \ldots \ldots \ldots \ldots \ldots \ldots \ldots \ldots \ldots$

Background and significance ............ 1

Statement of the Problem ............. 5

Purpose ............................ 5

Research Questions $\ldots \ldots \ldots \ldots \ldots \ldots \ldots \ldots \ldots$

Definition of Terms $\ldots \ldots \ldots \ldots \ldots \ldots \ldots \ldots$

2. REVIEW OF LITERATURE AND CONCEPTUAL

FRAMEWORK $\ldots \ldots \ldots \ldots \ldots \ldots \ldots \ldots \ldots \ldots \ldots . \ldots \ldots$

Background/Literature Review ........... 10

Medical Ability to Prolong Life .......... 10

Patient's Right to Self-Determination ...... 10

Relief of suffering ............... 12

The Nurse as Patient Advocate .......... 13

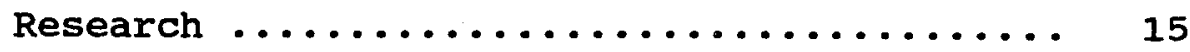

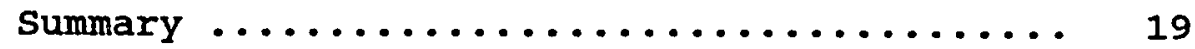

Conceptual Framework .................. 19

3. METHODOLOGY ....................... 24

Research Design .................... 24

Sample and setting ................. 24

Instrument $\ldots \ldots \ldots \ldots \ldots \ldots \ldots \ldots \ldots \ldots \ldots . \ldots \ldots$

Data Collection .................... 27

Data Analysis Procedures .............. 28 


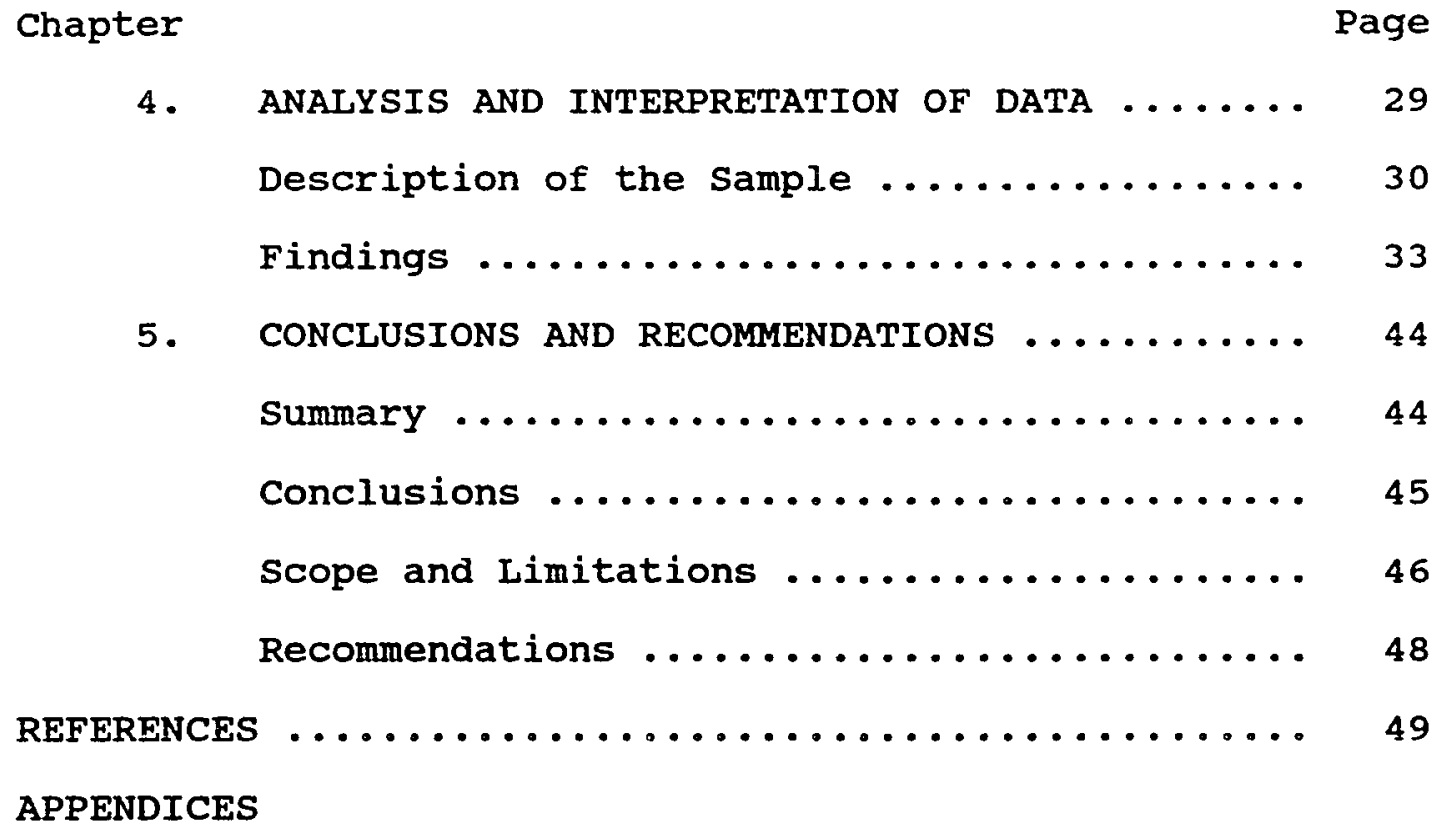

A. Questionnaire .................. 54

B. Permission Letter to Replicate Study .. 56

c. Cover Letter to Participants ........ 58 


\section{LIST OF TABLES}

Table

Page

1. Demographic Data of Respondents .......... 31

2. A Comparison of Educational level, Years of

Experience as Oncology Nurse, and Experienced

Loss of a Family Member/Close Friend for

Linder and Richardson Samples ......... 32

3. Voluntary Active Euthanasia Summarized

Information of Questionnaire ......... 34

4. ANOVA Summary Table of Attitude Scores for

Influence of Religion .............. 39

5. Comparison of Results of 7 Independent t-tests

Between Linder and Richardson Samples .... 42 
Chapter 1

INTRODUCTION

Background and significance

Voluntary active euthanasia and "voluntary dying" are among the controversial issues in health care today. Voluntary active euthanasia (VAE) is defined as allowing terminally ill patients with no more than 6 months to live the legal right to end their lives by a physician-assisted lethal injection (Filteau, 1991). Whether or not terminally ill patients have the legal right to ask for assistance to die is an ongoing debate. Legislative attempts to allow VAE have continued, although they have been consistently defeated. In recent years, proposed legislation for "death initiatives" has been particularly prevalent in the western region of the United States.

Public opinion polls have shown an increasing acceptance of voluntary active euthanasia as an option for incurable patients in California. By the mid-1980s, approval rates for active euthanasia reached over 50\% (Pletcher, 1992). In 1987, Americans Against Human Suffering proposed a legislative model, entitled "Human and Dignified Death Act" in California which would have "provided autonomy to an individual while establishing safeguards against potential abuse" (Pletcher, 1992, p. 314). If passed, this law would have allowed physicians to legally assist in terminating the lives of dying patients upon request. The Death with 
Dignity act stipulated that a written directive in a patient's medical record with two witnesses must be included, yet could be revoked at any time either orally or in writing (Pletcher, 1992). Only patients diagnosed by two physicians with an "incurable condition that would result in death within 6 months" were included (Pletcher, 1992, p. 315). A physician could honor the directive without fear of criminal penalty or refer to another physician if they personally opposed the voluntary active euthanasia (Pletcher, 1992). Since only 48\% favored the measure, the proposition did not receive the necessary number of signatures to be placed on the ballot (Parachini, 1989). However, what the Death with Dignity Act provided was a favorable reception for future legislative attempts.

Washington state voters narrowly defeated Initiative 119 in November 1991 (Cohen, Fihn, Boyko, Jonsen, \& Wood, 1994). Paralleling other referendums, Initiative 199 would have allowed a physician to administer a lethal injection to promote death if authorized by a terminally ill patient who had 6 months or less to live (Carson, 1992).

Surveys in March-April 1992 showed that "75\% of the California voters favored the basic concept of physician aid-in-dying" (Capron, 1993, p. 32). Those opposed on religious grounds remained relatively constant until the November 1992 elections (Capron, 1993). In that election, Proposition 161 would have authorized physicians to give 
mentally competent, terminally ill patients lethal injections or other medication to end their lives upon their request (Henshaw, 1995). Similar to the 1987 Death with Dignity Act, two physician opinions were needed to conclude that the patient's illness would result in death within 6 months. The safeguards of revoking the directive were similar to the 1987 Death with Dignity Act. Proposition 161 was narrowly defeated by California voters by $54 \%$ to $46 \%$. Voters feared that mistakes could be made and that psychological evaluations or a waiting period were required before a physician could assist in the termination of a patient's life (Shall We Pass, 1992). Oregon became the first state to pass legislation for the legalization of euthanasia in November 1994. Measure 16 was approved with a margin of $51 \%$ to $49 \%$. This measure allowed a patient to request a lethal dose of drugs if at least two physicians determined the person had less than 6 months to live (Oregon's Suicide, 1994). On December 7, 1994, the day before it was to become law, the constitutionality of this law was challenged. U.S. District Judge Michael Hogan stated, "the first suicide-assisted (euthanasia) law in this country deserved a thoughtful constitutional analysis" (Hearing sought, 1994).

On August 4, 1995, Judge Michael Hogan struck down as unconstitutional Oregon's assisted suicide measure. He stated that the measure "unfairly discriminated against the 
dying, and there was little assurance that only competent terminally ill persons would voluntarily die" (Assisted Suicide Banned, 1995). Hogan ruled that the euthanasia law violated the equal protection clause of the Constitution's 14th Amendment (Assisted Suicide Banned, 1995).

A new Death with Dignity Act (AB 1080), proposed by D. Martinez, is scheduled for a hearing in the California State Legislature in January 1996 (D. Martinez, California State Legislature, personal communication, April 20, 1995). The difference in this proposed bill is that a physician could prescribe the lethal dose of medication for terminally ill patients with 6 months or less of life expectancy, but not administer it. The physician would be immune from prosecution for providing the medication as written in the previous death with dignity acts (Henshaw, 1995).

Although the death with dignity acts have been consistently defeated, the growing strong public support sounds a loud warning for health care professionals. According to Capron (1993), "the defeat of the propositions should not obscure the remarkable fact that millions of people are so fearful of how they'll be treated by the health care system when they're very ill, that they'd rather be dead" (p. 32). Each death with dignity act has proposed a "rational alternative" for terminally ill patients to decide whether to seek assistance in dying at the end of their lives. According to Pletcher (1992), "there is no reason to 
believe that active euthanasia and assisted suicide will cease simply due to the current status of the acts" (p. 316). When statutes preventing abortion failed to eliminate the opportunity to get one, legalization provided a dignified and sanitary means of obtaining one by choice. Likewise, those afflicted with terminal illnesses deserve the alternative of a dignified death. According to law in most states, the right of an individual to terminate his/her life is prohibited, and the right of an individual to assist another in taking his/her life remains an area of legal debate (Pletcher, 1992).

statement of the Problem

oncology nurses care for terminally ill patients. They are exposed to death and dying on a regular basis. "Because of this, they may develop certain attitudes toward the process of dying" (Richardson, 1994, p. 348). Oncology nurses will be directly affected by the legalization of voluntary active euthanasia. They will be confronted with the controversial moral and ethical dilemmas legalization will present, mainly, the sanctity of life versus a death with dignity.

\section{Purpose}

The purpose of this study is to identify oncology nurses' attitudes toward the legalization of voluntary active euthanasia. Richardson's (1994) study identified oncology nurses' attitudes toward the legalization of 
voluntary active euthanasia and identified potential influential factors. She surveyed nurses residing in the midwestern states of Illinois, Indiana, Missouri, and Iowa. This study will be a replication identifying oncology nurses' attitudes in the western states of California, washington, and Oregon. Because of the growing trend for the legalization of euthanasia, particularly in the western states, this topic is timely. Comparisons will be made to determine if differences exist between attitudes of oncology nurses in the midwest and attitudes of oncology nurses in the western region of the United states towards legalized euthanasia. Exploring this issue may raise the consciousness level of oncology nurses, enhance knowledge about attitudes toward voluntary active euthanasia, and encourage involvement to support or oppose future legislation. Research Questions

The proposed research questions are:

1. What are the attitudes of oncology nurses toward the legalization of voluntary active euthanasia for terminally ill patients?

2. Is there a relationship between the presence of religious beliefs and attitudes toward voluntary active euthanasia?

3. Is there a relationship between personal experience with death and attitudes toward voluntary active euthanasia? 4. Is there a relationship between educational 
preparation and attitudes toward voluntary active euthanasia?

5. Is there a relationship between length of practice as an oncology nurse and attitudes toward voluntary active euthanasia?

6. Has the number of years of experience as an oncology nurse altered views toward voluntary active euthanasia?

7. Is there a difference in the attitudes of oncology nurses in the midwest and the oncology nurses in the west toward the legalization of voluntary active euthanasia?

$$
\text { Definition of Terms }
$$

This study will be a replication of Richardson's (1994) study using a different geographic population. Therefore, the definition of terms will be consistent with the definitions proposed in Richardson's (1992) study.

Attitude will be conceptually defined as a way to respond unfavorably or favorably to a person, institution, event, or an object (Davis \& Aroskar, 1983). Attitude will be operationally defined as positive or negative responses to five specific questions pertaining to voluntary active euthanasia on the questionnaire.

Oncology nurse will be conceptually defined as a licensed registered nurse who cares for cancer patients (Richardson, 1992) - Oncology nurse will be operationally defined as a member in 1995 of the oncology Nurses society living in California, Washington, and oregon. 
Religious beliefs will be conceptually defined as a person's belief in a divine command as revealed by the Bible or other book recognized by an organized religion. Religious beliefs will be operationally defined by positive responses to the statement, "Religion significantly influences my life" (Richardson, 1992, p. 10).

Personal experience will be conceptually defined as a death-related event that occurred within a person's lifetime that was perceived as significant to cause an adjustment or modification of the individual's value system about active euthanasia. Personal experience will be operationally defined by a positive response to the question, "Have you ever experienced the loss of a family member or a close friend to terminal illness" (Richardson, 1992, p. 10).

Terminally ill will be operationally defined as having less than 6 months to iive and no foreseeable recovery from the disease process (Richardson, 1994).

Voluntary active euthanasia will be operationally defined as allowing a terminally ill patient with 6 months to live, the legal right to end his/her life upon request with the assistance of a physician or a designee of the physician by means of a lethal injection (Richardson, 1994).

End their own life will be operationally defined as a terminally ill patient choosing to terminate his life without the assistance of a physician or designated health professional. In many states, the right of an individual to 
take his own life is illegal, just as the right of an individual to assist in the termination of a life is illegal. 
Cr. pter 2

REVIEW OF LITERATURE AND CONCEPTUAL FRAMEWORK

Background/Literature Review

The issues of legalization of euthanasia remain

controversial. Strong arguments have been articulated in the medical, nursing, and societal contexts by both the proponents and opponents of legalization.

Medical Ability to Prolong Life

Advances and improvements in Iife-sustaining technology have clouded the issue of the right to die. Terminally ill patients with little hope for recovery are kept alive by respirators, antibiotics, blood products, and many other forms of technology. Patients fear that their suffering will be prolonged by medical technology and that they will have little control over when they are permitted to die (Richardson, 1994). Families are challenged by the emotional and financial stresses of prolonged dying of loved ones (Richardson, 1994). Jameton (1977) identified the "nurse in the middle" phenomenon where he described that nurses were responsible for care but "lacked the authority to influence decisions that governed the care process" (Young, Volker, Reiger, \& Thorpe, 1993, p. 446).

Patient's Right to Self-Determination

The rights of an individual include autonomy or selfdetermination and privacy. The right to self-determination and autonomy is the individual's ethical right to refuse or 
request medical treatment. The protection from invasive or unwanted medicine is considered a part of the constitutional right to privacy (Coyle, 1992). Patients have both a legal and ethical right to consent to refuse treatment.

Individual autonomy supports the patient's control of the conditions of dying. According to Brock (1992), respecting the patient's choice about the circumstances of death will promote more compassionate care that is sensitive to individual needs. The affirmation of the right to autonomy is an affirmation of human dignity and the sanctity of life. The right to privacy protects the competent patient's decision about treatment even when that treatment is lifesaving.

Most states recognize an individual's right to refuse medical treatment based on the right to privacy and informed consent (Pletcher, 1992). In the case of cruzan v. Director, Missouri Department of Health (1990), the Missouri State supreme court ruled that state policy favored the preservation of life. Although Nancy Cruzan had been in a vegetative state for 7 years, the parents could obtain a termination order only by presenting clear and convincing evidence of the incompetent patient's intent to want to die (Pletcher, 1992). The parents were unable to produce the evidence, so the court denied the order to terminate her 1ife. The case was appealed to the United States Supreme court which narrowly ruled to uphold the state's decision. 
"Under the due process clause, a state may require that an incompetent person's wishes as to the withdrawal of life sustaining medical treatment be proven by clear and convincing evidence." Cruzan v. Director, (1990), 2855-2856.

Opponents of euthanasia argue that the relationships of health care providers with patients include certain responsibilities and obligations. Emphasis is on "healing, caring, relieving suffering, and promoting well-being" (Coyle, 1992, p. 43). Fowler (1988) states that the relationship between the health care provider and patient is based on trust. Permitting euthanasia makes patients less willing to discuss "poorly controlled symptoms for fear of a hastened death" (Coyle, 1992, p. 43). Thus, the relationship of trust may be sinaken.

\section{Relief of Suffering}

Nurses are frequently confronted with symptomatic and distressed terminally ill patients. According to young et al. (1993), nurses concerned with the relief of suffering "must adequately address the physical and psychological symptoms of pain so that patients do not view active euthanasia as their only choice of relief" (p. 451). According to Coyle (1992), nurses should concentrate on efforts for palliative relief with improved use and control of pain medication. According to the amended code of Ethics for Nurses, the "nurse may provide interventions in the dying patient even when the interventions entail substantial 
risks of hastening death" (California Nurses Association, 1990, p. 67).

Often the concept of terminality and suffering are considered as one, but "not all patients who suffer are terminal just as not all terminal patients suffer" (California Nurses Association, 1990, p. 20). Those patients who may die from chronic, progressive conditions may be interested in voluntary active euthanasia as well.

The Nurse as Patient Advocate

The professional nurse is expected to act as a patient advocate. The Code for Nurses (American Nurses Association, 1985) suggests that nurses are obligated to support the moral and legal rights of patients. The position statement on ethics in nursing clearly indicates that nurses should not deliberately terminate a patient's life. The position statement does not directly refer to euthanasia but refers to participation in capital punishment.

According to the American Nurses Association (1988): The goals of nursing are the promotion, maintenance, and restoration of health; the prevention of illness; and the alleviation of suffering. The social contract between nursing and society to meet these goals is based on a code of ethics that is grounded in the basic ethical principles of respect for persons, noninfliction of harm, and fidelity to recipients of nursing care. These principles command that nurses 
protect or preserve life, avoid doing harm and create a relationship of trust and loyalty with recipients of nursing action. Regardless of personal opinion of nurses on the moral appropriateness of capital punishment, either generally or specifically, it is a breach of the ethical tradition of nursing and its codes for nurses to participate in taking human life, even through a legally authorized civil or military execution. (p. 10)

Nurses traditionally support a patient's right to selfdetermination but "cannot be effective when they are compromised by the suspicion that they are engaged in intentionally taking life" (California Nurses Association Ethics Committee, 1987, p. 7).

An updated position statement of the California Nurses Association (1990) indicates that it "opposes active voluntary euthanasia and active involuntary euthanasia of the terminally ill, including actual participation by nurses, as a violation of both the code of Nurses and the moral tradition of the nursing profession" (p. 16). The strong position suggests that "the negative consequences for society as a whole, and for the nursing profession, are too serious to condone nurses' participation" (p. 16). According to the code for Nurses with interpretive statements (1985): the nurse's respect for the worth and dignity of the human being applies, irrespective of the 
nature of the health problem. It is reflected in care given the person who is disabled as well as one without disability, the recovering patient as well as the one in the last phase of life. This respect extends to all who require the services of the nurse for the promotion of health, the restoration of health, the alleviation of suffering, and the provision of supportive care to the dying. The nurse does not act deliberately to terminate the life of any person. (pp. 17-18) The amended Code of Nurses clearly states that the "nurse may provide interventions to relieve symptoms in the dying client even when the interventions entail substantial risks of hastening death" (California Nurses Association, 1990, p. 67) .

The issues of euthanasia for the nurse, if legalized, would present moral and ethical dilemmas. Nurses would be forced to choose between the "dignity of death" or an "abdication of responsibility to the patient who is dying" (Coyle, 1992, p. 41).

Research

Published research studies on nurses' attitudes toward legalized voluntary active euthanasia are limited. Slater (1987) found that nurses were concerned about physicians' lack of respect for terminally ill patients requesting active voluntary euthanasia. In his study, slater found 
that the nurses supported the patients' wishes in their role of patient advocate.

In a study by Jansson and Norberg (1989), "experienced" Swedish oncology nurses (those working with cancer patients for 4 to 25 years) were asked whether active euthanasia would be appropriate if the patient was suffering severely and dying. Of the 20 interviewed, only 3 said yes. The other 17 nurses were strongly opposed to the idea, referring to religious beliefs and the illegality of active euthanasia. None of the nurses felt that they could accept active euthanasia, even if it were legal, because "they would not be able to live with the knowledge that they have "killed the patient" (Jansson \& Norberg, 1989, p. 355).

A study by Hiller and Sugarman (1990) indicated that $76.2 \%$ of 193 long term care professionals supported legal options for terminally ill patients to end their lives. When asked whether medically incompetent terminally ill people should be kept alive by life support systems despite the wishes of their family, 77.58 of 191 long term care professionals responded no.

A study conducted at a general hospital in Tokyo, Japan, with 202 nurses showed that 23\% of the nurses would approve of euthanasia if the patient were terminally ill (Takeo, Satoh, Minamisawa, \& Miteh, 1991). In the same study, 63\% of the nurses responded that they would approve of euthanasia if they were terminally ill patients, while 
27\% disapproved (Takeo et al., 1991).

According to a study by Young et al. (1993), oncology nurses surveyed held varying beliefs about euthanasia. Beliefs ranged from a willingness to support these issues as a legitimate choice to support patients $(44 \%)$ to refusing to be involved (248). Many nurses viewed their role as patient advocates and euthanasia as a legitimate choice but not their personal choice.

The findings of Young et al. (1993) showed that $47 \%$ indicated they would vote to legalize euthanasia, while $46 \%$ indicated that they would not vote for legalization. Five percent were undecided about how they would vote. Geographic region varied significantly with how they would vote. Sixty percent of the nurses surveyed from the west (including California, Oregon, and Washington) and $57 \%$ of nurses from the southeast (including Florida, the Carolinas, and Georgia) voted to legalize euthanasia. Only $37 \%$ of midwest nurses and less than half of the nurses in all other regions indicated that they would vote for legalization (Young et al., 1993).

Young found that religious beliefs of oncology nurses affected attitudes about euthanasia. Catholic nurses were less likely to agree with the acceptability of euthanasia than those who were Protestant. Nurses who identified themselves as Jewish, Agnostic, or Atheist were strong supporters of voluntary active euthanasia (Young et al., 1993). 
Richardson's (1994) study found that $52 \%$ of oncology nurses in the midwestern states of Illinois, Indiana, Iowa, and Missouri agreed that terminally ill patients should have the legal option to end their lives; $36 \%$ disagreed, and $11 \%$ were undecided. Although the majority of respondents agreed that terminally ill patients should have the legal option to end their lives, $55 \%$ would not participate in voluntary active euthanasia even if the patient had requested it. of the respondents, $23 \%$ answered that they would participate, but $22 \%$ remained undecided (Richardson, 1994).

Results of the Richardson (1994) study indicated that 478 of the respondents would approve of voluntary active euthanasia if they were the patient. Approval for a family member was $44 \%$. In both situations, $41 \%$ disagreed with voluntary active euthanasia.

Educational preparation or the number of years of practicing oncology nursing did not affect attitudes toward the legalization of voluntary active euthanasia (Richardson, 1994). The only significant variable was religious beliefs. Like Young (1993), Richardson (1994) found that religion affected the respondents' attitudes toward the legalization of voluntary active euthanasia. sixty-four percent of nurses who strongly agreed that religious beliefs influenced their life were opposed to legalization of voluntary active euthanasia. Those who stated religion did not influence their lives $(27 \%)$ viewed voluntary active euthanasia as 
favorable.

\section{Summary}

The issues of euthanasia continue to be controversial. For nurses, the moral and ethical dilemmas of euthanasia pose many conflicts. The nurse must balance the role as patient advocate of the terminally ill patient and act accordingly. Is it a patient's right to control his/her dying, or is intentionally taking a life morally wrong under any circumstances?

There is a growing trend to legalize voluntary active euthanasia, particularly in the western region of the United States. Nurses must identify their attitudes regarding euthanasia. Young's (1993) study indicated that stronger support of voluntary active euthanasia by oncology nurses may have been related to prominent legislation activity. "By exploring these issues, nurses' "unique perspective" can assist in creating appropriate law for practice" (Young et al., 1993, p. 451).

Conceptual Framework

"Ethics consist of the why; morals consist of the ought" (Thompson \& Thompson, 1985, p. 4). The conceptual framework of this study is based on the work of Lawrence Kolberg $(1981,1984$ ) who developed the theory of moral development and moral reasoning. Kolberg's model of moral reasoning "demonstrates the relationship between moral values and attitudes" (Richardson, 1994, p. 349). Moral 
values are based on what is right and wrong in human behavior. Morals are the "shoulds and should nots of life, culture, society, and religion" (Thompson \& Thompson, 1985, p. 5)

Kolberg's (1981) theory shows that moral values are "acquired through reward, punishment, modeling, explanation, manipulation or identification with a culture, group or person" (p. 116). According to Kolberg (1984), moral values can be altered with life experiences. The oncology nurse may experience an interpersonal conflict if voluntary active euthanasia is legalized. Moral/ethical dilemmas of participation may arise. The nurse may be faced with a decision to make between his/her personal attitudes, religious beliefs, professional obligations, and the law.

The framework of Kolberg's theory of moral development is divided into six moral stages with three levels. "Moral development is growth and like all growth, takes place according to a pre-determined sequence" (Duska \& Whelan, 1975, p. 48). The model explains moral growth through stages of moral reasoning, personal attitudes, and ethical behavior and is chosen as the dominant theory of moral reasoning used by researchers in this area.

\section{Level I - Preconventional Level}

At this level, the child is responsive to cultural rules of right and wrong, of good and bad. Basically, the individual is egocentric and interprets moral behavior based 
on the consequences of action such as reward, punishment, exchange of favors.

Stage I. Heteronomous Morality: Avoidance of punishment is valued rather than the respect for authority.

Stage II. Instrumental Morality: Right action consists of satisfying one's own needs and occasionally the needs of others. Reciprocity is a matter of "I'Il scratch your back if you scratch mine," not of loyalty, gratitude, or justice. Level II - Conventional Morality

At this level, the attitude is not only one of conformity, but of loyalty and maintaining, supporting the expectations of the group, family, or nation regardless of the consequences.

Stage III. Mutual Morality: There is much conformity to stereotypical images of what is "natural" behavior. Behavior is frequently judged by intention like, "he means well." Approval is won by being nice.

Stage IV. Social System Morality: Right behavior consists of doing one's duty, showing respect for authority, and maintaining the social order for its own sake. Level III - Post-conventional, Autonomous, or Principled Morality

At this level, there is a clear effort to define moral values that are valid and applicable apart from the groups or authority holding these values. At this level, Kolberg (1984) states that an individual moves from a societal to a 
universal perspective.

Stage V. Social Contract Morality: This stage generally has utilitarian overtones. Right action tends to be defined in terms of general individual rights that have been examined critically by society. Do the greatest good for the largest number. This is the "official" morality of the American government and constitution.

Stage VI. Universal Ethical Morality: Right is defined by the universal principles of justice, equality of human rights, and the respect for the dignity of human beings as individuals.

Attitudes, according to Kolberg's (1981) theory, are driven by moral values and life experiences. Oncology nurses must adhere to the Code of Ethics and standards proposed by the profession of nursing. At the Level II of Conventional Morality, the attitude is of supporting the expectations of the group and by stage IV of doing one's duty to maintain order. Nursing professional standards maintain that participation in voluntary active euthanasia is prohibited.

If only the professional component of nursing is considered, nurses at the Level II of Conventional Morality would adhere to strict conformity of the group. Nursing professional standards maintain that participation in voluntary active euthanasia is prohibited. Yet, the experiences of the nurse, both personally and professionally, shape the moral and ethical development of 
the individual. Social values influence attitudes. With voluntary active euthanasia, personal experiences with a terminally ill friend or family may significantly alter the moral values development. Nurses faced with the issue of voluntary active euthanasia may move from the Level II or group norm in a direction of moral development of Level IV. Kolberg's Level IV is the morality that is different from authority or groups holding the values (Kolberg, 1984).

A choice to participate in legal voluntary active euthanasia may soon become a reality. Presently, the legal standards of society and the nursing profession differ. Kolberg's theory $(1981,1984)$ of moral development assists in explaining "moral growth through stages of moral reasoning, ethical behavior and personal attitudes" (Richardson, 1992, p. 15). 


\section{Chapter 3}

\section{METHODOLOGY}

\section{Research Design}

This research study used a descriptive comparative design. It was a replication of a study by Richardson (1994) which surveyed attitudes of oncology nurses toward the legalization of voluntary euthanasia in the midwestern states of Illinois, Indiana, Iowa, and Missouri. A comparison of the attitudes of oncology nurses toward the legalization of voluntary active euthanasia in the western states of California, Washington, and oregon to the midwestern states of Illinois, Indiana, Iowa, and Missouri was determined.

\section{Sample and setting}

A random sample of 450 nurses were chosen from the 1995 membership list of the oncology Nurses' Society. All nurses chosen were members who resided in the states of California, Oregon, and Washington. Nurses who were members of the Oncology Nurses' Society were an accessible and appropriate population for the research study. A random sampling ensured that the sample was representative of the population (LaBiondo-Wood \& Haber, 1990). A weakness of this sampling was that only nurses who were members of the Oncology Nurses' Society were invited to participate in the study. 
Instrument

The instrument used was the questionnaire developed by Richardson (1994) entitled "Questionnaire of oncology Nurses' Attitudes Toward Voluntary Active Euthanasia" (QONATVAE) (see Appendix A). Permission of the author to replicate her study of oncology nurses' attitudes toward the legalization of voluntary active euthanasia was received in writing (see Appendix B). The instrument used a Likert rating scale with seven questions as a means of measurement to determine :he attitudes of oncology nurses toward the legalization of active voluntary euthanasia. The coding of the Likert scale consisted of five categories. A code of "one" was assigned to strongly disagree, a code of "two" to disagree, a code of "three" to undecided, a code of "four" to agree, and a code of "five" to strongly agree.

The QONATVAE measured oncology nurses' attitudes toward the legalization of voluntary active euthanasia. The first three questions of the questionnaire were not numbered but measured the following:

1. Impact of education preparation as determined by the response to the first question requesting the subject to indicate the highest level of completed nursing practice. The categories were associate degree, diploma, bachelor's degree, graduate degree, and doctorate (see Appendix A). 2. Impact of years of practice as an oncology nurse on attitudes toward voluntary active euthanasia as determined 
by the response to the second question requesting the subject to indicate how many years of oncology practice were completed. The categories were: less than 1 year, 1-3 years, 4-7 years, and 8 plus years (see Appendix A).

3. Impact of personal experience regarding the loss of a family member or close friend to a terminal illness as determined by the response to the third question requesting the subject to indicate yes or no (see Appendix A).

The next section of the gONATVAE consisted of seven questions numbered 1 to 7 that measured the following:

1. Attitudes of oncology nurses toward the legalization of voluntary active euthanasia. A Likert scale was used to measure responses to questions $1,2,3,5$, and 6 which pertained to attitudes (see Appendix A).

2. Impact of religious beliefs on attitudes toward voluntary active euthanasia. A Likert scale was used to measure responses to question 7 which pertained to the influence of religion (see Appendix A).

3. Impact of personal experience on attitudes toward the legalization of voluntary active euthanasia. A Likert scale was used to measure responses to questions 5 and 6 which pertained to self or a family member (see Appendix A).

4. Impact of experience as an oncology nurse in altering attitudes toward voluntary active euthanasia. A Likert scale was used to measure responses to question 4 which pertained to the influence of oncology nursing 
experience (see Appendix A) .

An additional demographic section of questions $A-E$ was added by the researcher to profile the background of the respondents. Categories included for question $A$ were gender: male or female. Categories for question B were age group: 20-30 years, 31-40 years, 41-50 years, 51-60 years, and over 60 years. Categories for question $C$ were religious affiliation: Catholic, Protestant, Jewish, Atheist, or other. Categories for question D were employment status: full time, part time, unemployed, or retired. Categories for question $\mathrm{E}$ categories were: primary practice settings of hospital, clinic, hospice, home health care, or other (see Appendix A for copy of instrument).

Data collection

Prior to data collection, approval for this study was obtained from San Jose State University Human Subjects Institutional Review Board. Questionnaires were mailed to all participants in the study. The purpose of the study was explained in a cover letter. Included in the letter were instructions to return the completed questionnaire in the return self-addressed envelope provided (see Appendix $c$ ). Return of the questionnaire served as informed consent. A returned, unmarked mailed questionnaire ensured anonymity of the participants.

Confidentiality of the subjects' responses was maintained. Only group data were reported. The questionnaire 
measured attitudes and did not ask subjects whether or not they had participated in activities related to voluntary active euthanasia, an illegal activity. The subjects were not asked to provide any information which could lead to civil or criminal liability (Richardson, 1992). The questionnaires have been securely locked in a filing cabinet in the researcher's office. The researcher is the only person to have access to the filing cabinet.

Data Analysis Procedures

The data were analyzed by a statistician using the computer program, statistical Package for the Social Sciences (SPSS). SPSS was used to calculate descriptive data of frequencies, percentages, means, and standard deviations from all data collected. SPss was used to calculate analysis of variance for all questions on QONATVAE except questions $A-E$. Independent $t$-tests were calculated for questions 1-7 to compare the results of Richardson's data to this study and to determine differences. The level of significance for the statistical test was set at $p<0.05$. 
Chapter 4

ANALYSIS AND INTERPRETATION OF DATA

The data from this study were analyzed to determine attitudes of oncology nurses residing in the western region of the United States (California, Washington, and Oregon) toward the legalization of voluntary active euthanasia. A comparison was made to determine if differences existed between Richardson's (1994) study of oncology nurses residing in the midwestern region of the United states (Illinois, Iowa, Missouri, and Indiana) towards the legalization of voluntary active euthanasia. All nurses who participated were randomly chosen from the oncology Nurses' Society membership list.

The research questions were:

1. What are the attitudes of oncology nurses toward the legalization of voluntary active euthanasia for terminally ill patients?

2. Is there a relationship between the presence of religious beliefs and attitudes toward voluntary active euthanasia?

3. Is there a relationship between personal experience with death and attitudes toward voluntary active euthanasia?

4. Is there a relationship between educational preparation and attitudes toward voluntary active euthanasia?

5. Is there a relationship between length of practice 
as an oncology nurse and attitudes toward voluntary active euthanasia?

6. Has the number of years of experience as an oncology nurse altered views toward voluntary active euthanasia?

7. Is there a difference in the attitudes of oncology nurses in the midwest and the oncology nurses in the west toward the legalization of voluntary active euthanasia?

Description of the Sample

Four hundred fifty questionnaires were mailed directly to the subjects and 262 were returned, a response rate of 58\%. No follow up was utilized.

Demographic data indicated that the majority of the sampled respondents were female (98\%). Two age groups made up the majority of the sample: $41-50$ years (40\%) and 31-40 years (31\%). Thirty four percent of the respondents indicated that their religious affiliation was catholic (34\%), and $38 \%$ were Protestant.

The majority of the sample respondents worked fulltime (68\%), and 50\% responded the primary practice setting was the hospital. Table 1 displays the demographic data of the respondents.

A comparison of this study sample was made to Richardson's (1994) sample regarding the educational level of respondents, years of practice as an oncology nurse, and the experience of a loss of a family member or close friend to a terminal illness. Table 2 displays the comparative 
Table 1

Demographic Data of Respondents $(N=262)$

\begin{tabular}{|c|c|c|}
\hline Descriptors & $\underline{\mathbf{n}}$ & $\underline{8}$ \\
\hline $\begin{array}{l}\text { Gender } \\
\text { Male } \\
\text { Female }\end{array}$ & $\begin{array}{r}6 \\
252\end{array}$ & $\begin{array}{r}2 \\
98\end{array}$ \\
\hline $\begin{array}{l}\text { Age Group } \\
20-30 \text { years } \\
31-40 \text { years } \\
41-50 \text { years } \\
51-60 \text { years } \\
\text { over 60 years }\end{array}$ & $\begin{array}{r}20 \\
82 \\
104 \\
50 \\
6\end{array}$ & $\begin{array}{r}8 \\
31 \\
40 \\
17 \\
2\end{array}$ \\
\hline $\begin{array}{l}\text { Religious Affiliat } \\
\text { Catholic } \\
\text { Protestant } \\
\text { Jewish } \\
\text { Atheist } \\
\text { Other }\end{array}$ & $\begin{array}{r}88 \\
98 \\
9 \\
5 \\
58\end{array}$ & $\begin{array}{r}34 \\
38 \\
4 \\
2 \\
23\end{array}$ \\
\hline $\begin{array}{l}\text { Employment status } \\
\text { Fulltime } \\
\text { Parttime } \\
\text { Unemployed } \\
\text { Retired }\end{array}$ & $\begin{array}{r}177 \\
75 \\
6 \\
2\end{array}$ & $\begin{array}{r}68 \\
29 \\
2 \\
.8\end{array}$ \\
\hline $\begin{array}{l}\text { Primary Practice Se } \\
\text { Hospital } \\
\text { Clinic } \\
\text { Hospice } \\
\text { Home health care } \\
\text { Other }\end{array}$ & $\begin{array}{r}131 \\
47 \\
13 \\
22 \\
48\end{array}$ & $\begin{array}{r}50 \\
18 \\
5 \\
8 \\
18\end{array}$ \\
\hline
\end{tabular}


Table 2

A Comparison of Educational Level, Years of Experience as oncology Nurse, and Experienced Loss of a Family Member/Close Friend for Linder and Richardson Samples

\section{Linder* Richardson**}

Educational Level of Respondents

$\begin{array}{lrr}\text { Associate Degree } & 18 \% & 25 \% \\ \text { Diploma } & 12 \% & 29 \% \\ \text { Bachelor Degree } & 47 \% & 34 \% \\ \text { Graduate Degree } & 21 \% & 9 \% \\ \text { Doctorate Degree } & 2 \% & 2 \% \\ \text { Years of Experience as oncology } & \\ \text { Nurse } & 2.3 \% & \\ <1 \text { year } & 9.6 \% & 1 \% \\ 1-3 \text { years } & 22 \% & 16 \% \\ 4-7 \text { years } & 66 \% & 39 \% \\ 8+\text { years } & 45 \%\end{array}$

Experienced Loss of Family Member or Close Friend to a Terminal

I1lness

$\begin{array}{lll}\text { Yes } & 77 \% & 80 \% \\ \text { No } & 23 \% & 30 \%\end{array}$

Note. $*$ Linder $=1996$ study $; * *$ Richardson $=1994$ study . 
percentages between the two study samples.

The samples were similar in all regards except the educational level of the respondents. Richardson's (1994) sample of midwestern U.S. oncology nurses had a majority of bachelor's degrees (34\%) and associate degrees/diplomas (54\%) as compared to the sample of western U.S. oncology nurses with bachelor's degrees (47\%) and graduate degrees (21\%). The majority of oncology nurses in both samples had been practicing for 8 years or more and had experienced the loss of a family member or close friend to a terminal illness.

\section{Findings}

The data for research questions 1 to 7 are displayed in Table 3. Table 3 summarizes the frequency distribution for research questions 1 to 7 according to the Likert scale. Research question \#1. What are the attitudes of oncology nurses toward the legalization of voluntary active euthanasia?

The majority $(68.7 \%, \underline{n}=180)$ of the respondents agreed that terminally ill patients should have the legal option to end their life. Written comments by participanis expressed a variety of opinions. One nurse wrote, "I realize my very strong feelings that all persons should have the right to determine their destiny, the decision to live or die, and my uncertainty regarding assisting a death is a dichotomy. Perhaps this characterizes the issue and demonstrates its 


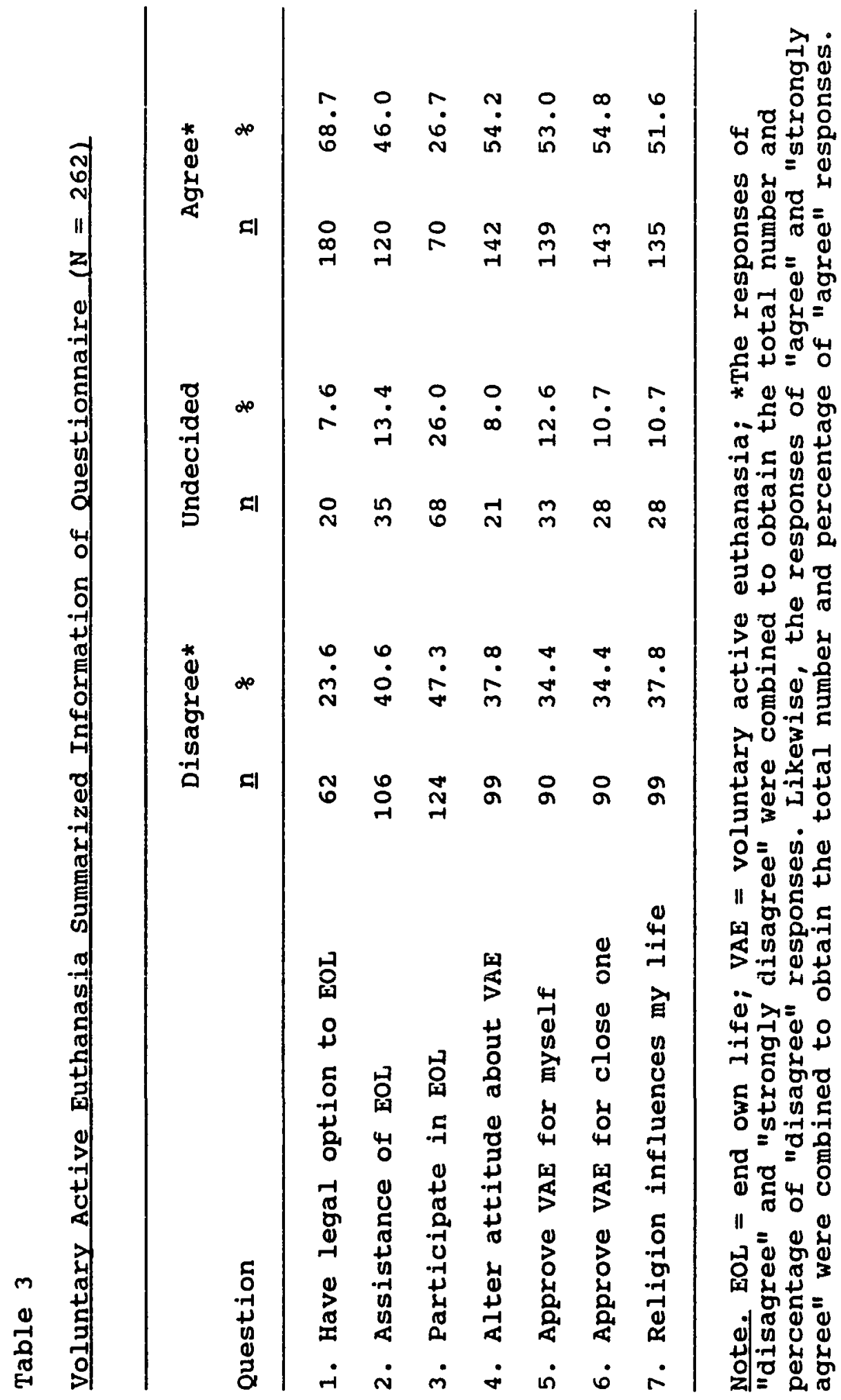


complexity." Some comments supported voluntary active euthanasia: "I may not choose to exercise my legal right to voluntary active euthanasia if terminally ill, but feel the choice should be available."

A nurse that opposed euthanasia wrote, "I have been in oncology nursing for $23+$ years and have taken care of adults as well as children in clinics, acute care, and home care/hospice. I have never felt that voluntary active euthanasia has been an appropriate option for cancer patients, especially the terminally ill. I have lived through multiple changes in therapy and improvements in pain control and know there are clinical options to keep patients comfortable until they die. Killing a person, or assisting them in committing suicide, is not in keeping with our professional commitment to health care." Another nurse commented, "If we were doing a better job of keeping patients comfortable, this (euthanasia) would not be such a big issue. I think everyone should have a choice, but we should give them better reasons to remain alive."

A smaller percentage $(46 \%, \underline{n}=120)$ of respondents agreed with a legal right to end one's life if it required assistance from health care workers (see Table 3, question \#2). Those that disagreed that health care workers should be the ones to assist in ending life were $40.6 \%(\underline{n}=106)$, and $13.4 \%(\underline{n}=35)$ were undecided.

One nurse commented about the trust relationship health 
care professionals have with patients regarding euthanasia. She wrote, "While I do not believe in euthanasia, I do believe that terminally ill patients should be kept comfortable by whatever means is needed even if it means administering medications that might hasten death. I believe the legalization of euthanasia devalues life . . legal sanctions can lead to abuse. I am told by nurses from Holland (euthanasia is accepted) that many of the elderly fear health care professionals because they are afraid their lives will be taken without their consents. The fear may not be realistic, but nothing should be done to decrease the level of trust the very ill have in those who care for them."

While a majority of the respondents agreed that terminally ill patients should have the legal option to end their lives, $47.3 \%(\underline{n}=124)$ would not participate in voluntary active euthanasia even if were legal and it was requested by the patient (see Table 3, question \#3). Those that would participate were $26.78(\underline{q}=70)$, and $26 \%(\underline{n}=68)$ remained undecided.

Many nurses who supported voluntary active euthanasia for patients commented that they could not participate in the act. One nurse wrote, "Although I agree with the patient's right to choose to end his life, I do not feel it is my right as a health care practitioner to bring about a death. I do feel that it is within my right to keep the 
patient as painfree and comfortable as possible." Another wrote, "I will not stop trying to make my patients and their families more comfortable. But I will not help to kill them, nor will I encourage them to kill themselves. I believe there is a reason for their continued existence."

only a slight difference was noted in approval for voluntary active euthanasia for oneself (53\%) and a family member (55\%). Thirty four percent disagreed with voluntary active euthanasia in both situations (see Table 3, questions \#5 and \#6). Thirteen percent were undecided regarding the approval of voluntary active euthanasia for oneself, and $11 \%$ were undecided regarding voluntary active euthanasia for a terminally ill family member. One nurse commented, "Although I agree that people have a choice about how they should die in the event of a terminal disease, I myself would not be able to be an active participant even with my own family member. I do support the legality of people being able to do it, but I should not as a health care professional be put in a position of having to do it."

The majority of participants agreed $(51.6 \%, \underline{n}=57)$ that religion significantly influenced their life (see Table 3, question \#7). Those that disagreed were $37.8 \%(\underline{n}=99)$, while $10.7 \%(\underline{n}=28)$ were undecided. One nurse wrote, "I have no problem in giving any amount of medication to give comfort or induce sleep, but $I$ do not feel that I have the option or right to assist anyone to end their life. I feel 
that God is the giver of life and the one who takes it from us." Another nurse commented, "Religion is important in my life but does not in any way affect how I feel about euthanasia. Terminally ill patients have the right to make choices regarding their life but do not have the right, nor should they expect other persons to participate in carrying out those decisions."

Research Question \#2. Is there a relationship between the presence of religious beliefs and attitudes toward voluntary active euthanasia?

Analysis of variance determined that there was a statistically significant difference in means of attitudes of oncology nurses toward voluntary active euthanasia related to the presence of religious beliefs (see Table 4). This relationship was statistically significant for five attitudes sampled (legal option, assistance, participation, VAE for self, and VAE for close one) at $\mathfrak{p}<.001$. Furthermore, there was a statistically significant relationship between prior experiences altering attitudes and the presence of religious beliefs, suggesting that the presence of religious beliefs may be a more accurate predictor of attitudes than prior experiences (see Table 4, question \#4).

Research Question \#3. Is there a relationship between personal experience with death and attitudes toward voluntary active euthanasia?

An analysis of variance determined that there was no 
Table 4

ANOVA Summary Table of Attitude Scores for Influence of Religion

$1 N=2621$

\begin{tabular}{lllllll}
\hline Question & $\underline{d E}$ & $\underline{S}$ & $\underline{M}$ & $\underline{f}$ & $\underline{P}$ \\
\hline
\end{tabular}

1. Have legal option to

EOL

2. Assistance of EOL

3. Participate in EOL

$\begin{array}{rrrrr}4 & 98.993 & 24.748 & 14.35 & .0000 * \\ 4 & 101.370 & 25.342 & 13.99 & .0000 * \\ 4 & 93.145 & 23.286 & 14.57 & .0000 *\end{array}$

4. Alter attitude about

VAE

5. Approve VAE for mygelf

6. Approve VAE for

close one

4

27.195

6.799

$3.52 \quad .0081$

$4 \quad 89.794$

22.448

11.18 .0000 *

4

97.407

24.352

13.00

$.0000 *$

Note. $\mathrm{EOL}=$ end own 1ife; $\mathrm{VAE}$ = voluntary active euthanasia;

$\underline{M S}=$ means of the squares; $\underline{\underline{f}}=$ frequency; ${ }^{*} \underline{\underline{p}}=$ significance $\underline{p}<0.0001$. 
significant difference in attitude toward voluntary active euthanasia related to personal experiences with death.

Research Question \#4. Is there a relationship between educational preparation and attitudes toward voluntary active euthanasia?

Results of analysis of variance determined that there was no significant difference in attitude toward voluntary active euthanasia related to educational preparation.

Research question \#5. Is there a relationship between the length of practice as an oncology nurse and attitudes toward voluntary active euthanasia?

Results of analysis of variance determined that there was no significant difference in attitude toward voluntary active euthanasia related to length of practice as an oncology nurse.

Research Question \#6. Has the number of years of experience as an oncology nurse altered views toward voluntary active euthanasia?

Analysis of variance determined that there was no significant difference in attitude toward voluntary active euthanasia related to years of experience altering views toward voluntary active euthanasia. However, the majority of oncology nurses $(54.2 \%, \underline{n}=142)$ agreed that experiences as an oncology nurse had altered their attitudes about voluntary active euthanasia (see Table 3, question \#4). The nurses that disagreed were $37.8 \%(\underline{n}=99)$, and $8 \%(\underline{n}=21)$ 
were undecided that experience as an oncology nurse had altered their attitude about voluntary active euthanasia. One nurse commented, "I have seen much suffering and extreme pain in patients as well as loved ones. I strongly believe that not only should we have the right to controlling our lives, but if necessary our own deaths."

Research Question \#7. Is there a difference in the attitudes of oncology nurses in the midwestern U.S. and oncology nurses in the western U.S. regarding the legalization of voluntary active euthanasia?

The study findings indicated that there were statistically significant differences in means of attitudes of oncology nurses in the midwestern U.S. and oncology nurses in the western U.S. regarding the legalization of voluntary active euthanasia. Independent t-tests, means, and standard deviations were done to compare the data from questions \#1 to \#7 of this study with Richardson's (1994) data (see Table 5). The independent t-tests were done to determine if there were differences in the attitudes toward the legalization of voluntary active euthanasia between midwestern and western oncology nurses. The results for question \#1 $(t(2.86), \underline{p}=.004)$, question \#2 ( $t(2.19)$, $\mathfrak{p}=0.29)$, and question $\# 7(t(-2.55), \underline{p}=.011)$ indicated $a$ statistically significant difference in means of attitudes between midwestern and western U.S. oncology nurses toward the legalization of voluntary active euthanasia. 
Table 5

Comparison of Results of 7 Independent $t$-tests Between

Linder and Richardson Samples

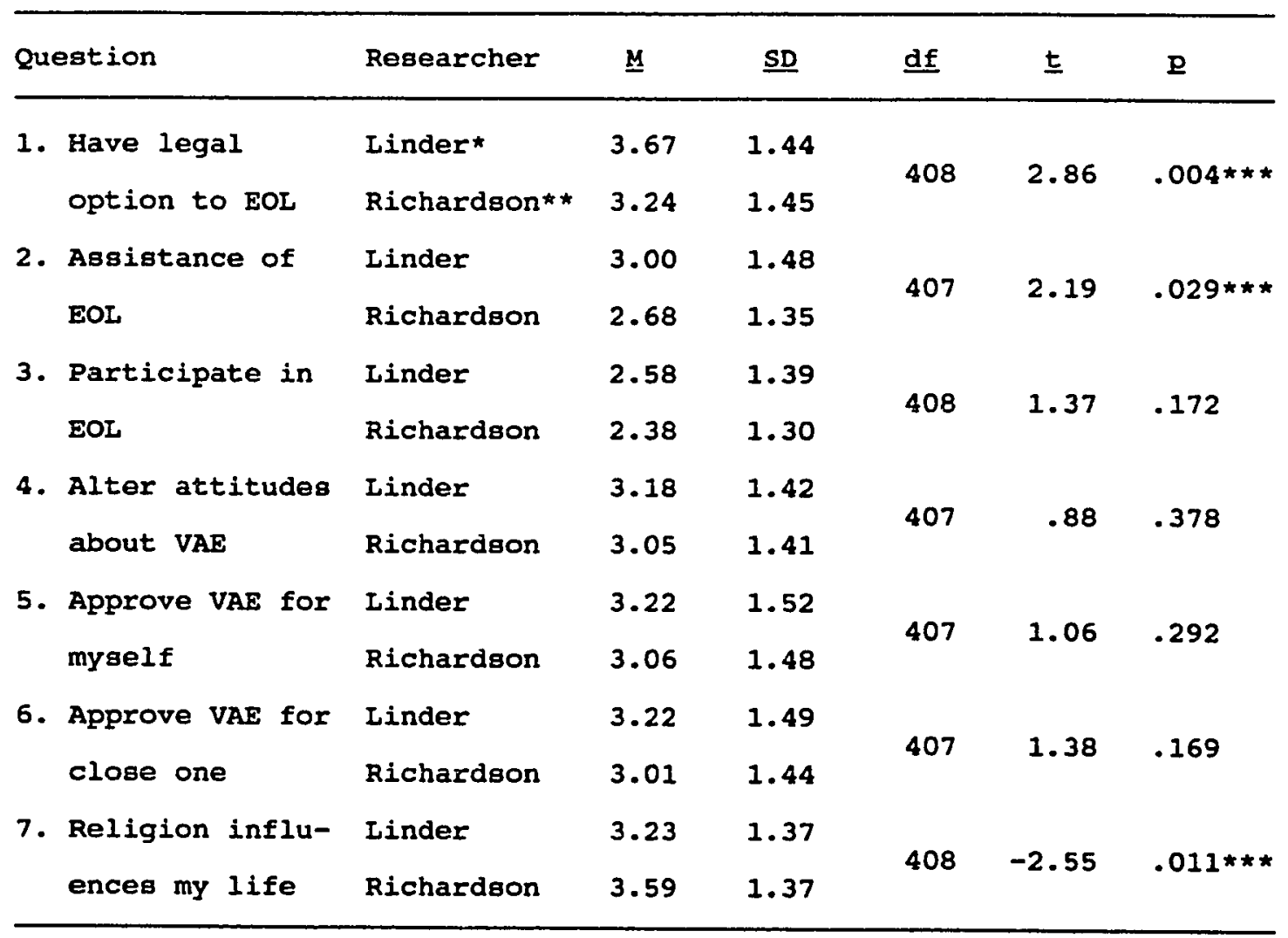

Note. $E O L=$ end own life; VAE = voluntary active euthanasia; $M$ = mean; $\underline{S D}=$ standard deviation; $\underline{d f}=$ degrees of fxeedom; $t=$ computed value of t-test; *Linder $=1996$ study; $* *$ Richardson $=1994$ study; $* \star \star D=$ significance $\mathrm{p}<.05$. 
Nurses in the western U.S. were more likely to agree that patients should have the legal option to end their own lives and that patients should have assistance in ending their own lives than oncology nurses in the midwest. Attitudes of oncology nurses in the west were less likely to be influenced by religion than attitudes of oncology nurses in the midwest. 


\section{Chapter 5}

\section{CONCLUSIONS AND RECOMMENDATIONS}

Summary

This study used a descriptive comparative design to explore oncology nurses' attitudes toward the legalization of voluntary active euthanasia. Oncology nurses were randomly selected from the 1995 oncology Nurses Society membership and resided in the western states of California, Oregon, and Washington. The study was a replication of a study by Richardson (1994) who explored oncology nurses' attitudes toward the legalization of voluntary active euthanasia in the midwestern states of Illinois, Indiana, Missouri, and Iowa. A comparative analysis of the two groups showed significant differences in the attitudes of oncology nurses based on geographical location. This study was part of a larger goal to raise the consciousness level of oncology nurses, enhance knowledge about attitudes toward voluntary active euthanasia, and encourage involvement to support or oppose future legislation.

The study sample consisted of 262 returned questionnaires $(58 \%)$ of the 450 mailed questionnaires. The data collection instrument was the "Questionnaire of Oncology Nurses Attitudes Toward the Legalization of Voluntary Active Euthanasia" (QONATLVAE). The questionnaire consisted of three questions that were not numbered regarding the highest completed nursing educational 
experience, length of time practicing oncology nursing, and loss of a family member or close friend to a terminal illness. Questions 1 to 7 were statements which used a Likert scale to gather data about attitudes toward the legalization of voluntary active euthanasia. The Likert scale measured responses from 5 - strongly agree, 4 - agree, 3 - undecided, 2 - disagree, to 1 - strongly disagree. A demographic section of questions $A-E$ was added by the researcher to profile the respondents regarding gender, age, religious affiliation, employment status, and primary practice setting.

A comparative analysis of the two study groups showed significant differences in the attitudes of oncology nurses toward the legalization of voluntary active euthanasia based on geographical location. A statistically significant relationship was found between attitudes of oncology nurses in the western U.S. and midwestern U.S. regarding the legal option of patients to end their lives, assistance from health care workers to end their lives, and the influence of religion toward voluntary active euthanasia.

\section{Conclusions}

The findings of this study were congruent with Richardson's (1994) study. Findings from both studies indicate a growing support by the majority of oncology nurses for patients' decisions to end their own lives. This support appears to be greater in the western region of the 
United states.

However, support appears to diminish as nurses perceive a closer involvement or the need for more active assistance for patients ending their own lives. Again, support appears stronger in the western United States. Religion appears to be less of an influence on attitudes toward the legalization of voluntary active euthanasia with western oncology nurses than in the midwest.

The controversial issues of voluntary active euthanasia for oncology nurses caring for terminally ill patients will continue. Continued education and discussion are important for oncology nurses who may face the moral and ethical dilemmas as the legalization of voluntary active euthanasia continues to gain support.

Scope and Limitations

Although the study samples were similar in years of practice and those that had experienced the loss of a family member/close friend to a terminal illness, the perceived differences in attitudes between the midwestern and western regions of the U.S. might be associated with educational preparation. This study sample represented a randomly selected population of oncology nurses with a majority of bachelor's degrees (47\%) and graduate degrees (21\%) as compared to Richardson's (1994) sample of diplomas/associate degrees (54\%) and bachelor's degrees (34\%). Further analysis would be necessary to determine if the differences in 
educational preparation of the two samples were statistically significant.

Increased activity of legislation in the western region of the U.S. in the past 5 years might be associated with perceived differences in attitudes toward the legalization of voluntary active euthanasia between oncology nurses in the midwestern and western region of the United states. Oncology nurses in the western U.S. may have an increased awareness and consideration of issues of voluntary active euthanasia due to increased proposals for legalization in the western states of California, Oregon, and Washington compared to the midwestern oncology nurses in Richardson's (1994) study. Further study may be indicated to compare the study groups during the same year and determine whether increased knowledge and legislation has an impact regarding attitudes of oncology nurses in different geographical regions of the United States.

Attitudes of oncology nurses in the midwestern U.S. were more influenced by religion than oncology nurses in the western region. This perceived difference in attitudes might be associated with the personal meaning of religion. Perhaps the diversity of religion or influence of religion is not viewed as strongly in the western United States. Further study is indicated to determine what aspects of religion or spirituality determine the differences in attitudes of oncology nurses regarding the legalization of voluntary 
active euthanasia.

$$
\text { Recommendations }
$$

Based on the positive return of the questionnaire and the statistically significant relationship between geographical region and the attitudes of oncology nurses toward the legalization of voluntary active euthanasia, more research is needed. The following recommendations are made based on the findings of this study:

1. For future reliability, the study should be replicated with other geographical regions of the United states.

2. Further research to explore the relationship of religion to attitudes toward voluntary active euthanasia should be conducted. Investigations to determine if religious affiliation or religious practices, such as frequency of attending religious services and spirituality, are related to religious influences should be conducted.

3. The gONATLVAE was expanded with demographic information. An expansion of the questionnaire might include the use of multiple questions with different forms such as a case scenario that would measure the same subjective material, adding validity to the questionnaire. 
REFERENCES 
References

American Nurses Association. (1985). Code for nurses with interpretative statements. Kansas City, Mo: Author.

American Nurses Association. (1988) . Ethics in nursing: Position statements and guidelines. Kansas City, Mo: Author.

Assisted suicide banned in oregon last year, voters had ok'd measure. (1995, August 4). San Jose Mercury News, p. A4.

Brock, D. W. (1992). Voluntary active euthanasia. Hastings Center Report, 22(2), 44-51.

California Nurses' Association. (1990). Ethics: Principles and issues, Vol. 2, San Francisco: Author.

California Nurses' Association Ethics Committee. (1987). California Nurses' Association Ethics Committee position statement on active euthanasia for the terminally i11. San Francisco: Author, 1-10.

Capron, A. M. (1993). Even in defeat, proposition 161 sounds a warning. Hastings Center Report, 23 (1), 32-33.

Carson, R. (1992). Washington's I-119. Hastings Center Report, 22 (2), 7-9.

Cohen, J., Fihn, S., Boyko, E., Jonsen, A., \& Wood, R. (1994). Attitudes toward assisted suicide and euthanasia among physicians in Washington State. New England Journal of Medicine, 331, 89-94.

Coyle, N. (1992). The euthanasia and physician-assisted suicide debate: Issues for nursing. Oncology Nursing Forum, 
$\underline{19}(7), 41-45$.

Cruzan v. Director, Missouri Department of Health, 110

S. Ct. 2841 (1990).

Davis, A. J., \& Aroskar, M. (1983). Ethical dilemmas

and nursing practice (2nd ed.). Norwalk, CT: Appletoncentury-crofts.

Duska, R., \& Whelan, M. (1975) . Moral development. New York: Paulist Press.

Filteau, J. (1991, September 22) . Condemn euthanasia moves society at a "critical juncture," says top bishops' panel. The catholic Post, 1.

Hearing sought on oregon measure dying patients, doctor to testify. (1994, December 9). San Jose Mercury News, p. A18.

Henshaw, J. (1995, April 16). Bills would ok doctor's help with suicide. San Jose Mercury News, p. B3.

Hiller, M. D., \& Sugarman, D. B. (1990). Euthanasia and long term care. Journal of Long Term Administration, 18 (4), 23-30.

Jameton, A. (1977). The nurse: When roles and rules conflict. Hastings Center Report, I(4), 22-23.

Jansson, L., \& Norberg, A. (1989) . Ethical reasoning concerning the feeding of terminally ill cancer patients. Cancer Nursing, $12,352-358$.

Kolberg, L. (1981). The philosophy of moral development. Philadelphia: Harper \& Row. 
Kolberg, L. (1984). The psychology of moral

development. Philadelphia: Harper \& Row.

LoBiando-Wood, G., \& Haber, J. (1990). Nursing research

(2nd ed.). St. Louis, Mo: C. V. Mosby Company.

Oregon's suicide law is put on hold. (1994, December

28) - San Jose Mercury News, p. A13.

Parachini, A. (1989). The California humane and

dignified death initiative. Hastings Center Report, 19(1), 10-12.

Pletcher, R. A. (1992). Assisted suicide for the terminally ill: The inadequacy of current legal models to rationally analyze voluntary active euthanasia. Criminal Justice Journal, 13(275), 303-317.

Richardson, D. S. (1992). Oncology nurses' attitudes toward the legalization of voluntary active euthanasia. Unpublished master's thesis, Bradley University, Peoria, IL.

Richardson, D. S. (1994). Oncology nurses' attitudes toward the legalization of voluntary active euthanasia. Cancer Nursing, 17, 348-354.

Shall we pass the "Death with Dignity Act?" (1992, Septmeber 27) - San Jose Mercury News, p. C6.

slater, P. (1987). The good death: Registered nurses' concerns about ethical issues. The Australian Journal of Advanced Nursing, 4(4), 16-28.

Takeo, K., Satoh, K., Minamisawa, H., Miteh, T. (1991). Health workers' attitudes toward euthanasia in 
Japan. International Nurses' Review, 38(2), 45-48.

Thompson, J. E., \& Thompson, H. (1985) . Bioethical

decision making for nurses. Norwalk, CT: Appleton-CenturyCrofts.

U.S.C.A. Const. Amend. 14; V.A.M.S. $\$ 459.010$.

Young, A., Volker, D., Reiger, P. \& Thorpe, D. (1993).

Oncology nurses' attitudes regarding voluntary physicianassisted dying for competent terminally ill patients.

Oncology Nursing Forum, 20, 445-450. 


\begin{abstract}
APPENDIX A
Questionnaire of Oncology Nurses' Attitudes Toward the Legalization of Voluntary Active Euthanasia
\end{abstract}




\section{Questionnaire of Oncology Nurses' Attitudes Toward}

the Legalization of Voluntary Active Euthanasia*

Please answer the following questions to the best of your

ability by completely darkening the oval you select:

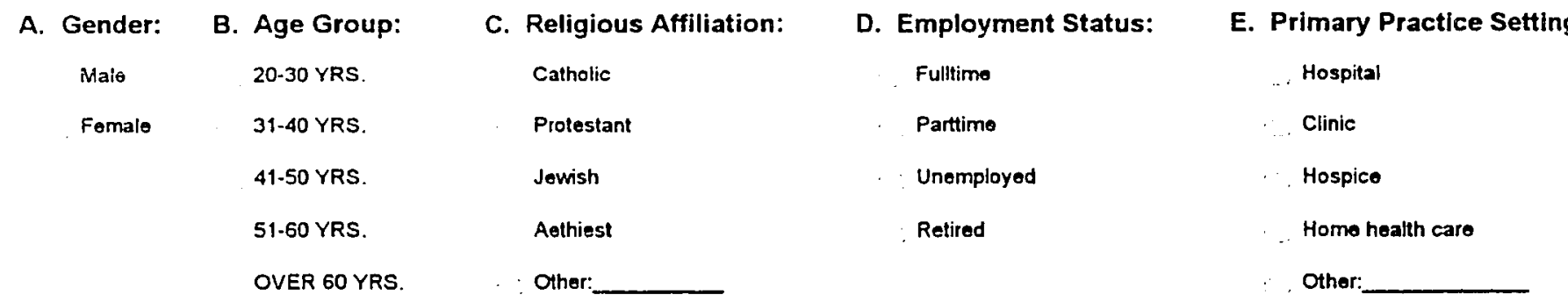

What is your highest completed nursing educational experience:

Associate degree
Diploma
Bachelor degree
Graduate degree
Doctorate

Associate degree

(n)

How long have you been practicing oncology nursing:
-. loss than 1 year
$\cdots, 1-3$ years
$4 \cdot 7$ years

8 plus years
Have you experienced the loss of a family member or a close friend to a terminal illness:

YES

NO

- 1. Terminally ill patients should have the legal option to end their life.

2. Terminally ill patients should have the legal option to end their life with assistance from health care workers.

3. If legal, I would participate in voluntary active euthanasia on request for the terminally ill.

4. Experience as an oncology nurse has altered my attitude about voluntary active euthanasia.

5. If I were the terminally ill patient I would approve of voluntary active euthanasia.

6. I would approve of voluntary active euthanasia for a terminally ill family member.

- 7. Religion significantly influences my life.

*Optional: If you would like, include any feelings or opinions you may have about this subject on the back of this page. 


\section{APPENDIX B \\ Permission Letter to Replicate Study}


Many thanks for your letter and your interest in replicating my study. It is my pleasure to be of assistance to you. I hope we would be of most interest and future on this research topic. It once you complete your study.

The information I have enclosed may answer the questions you had support is vital and keeps one focused.
sucknowledgement page for

Best Wishes

Deborah Richardson

Phone w 309-655-2939

$4 / 28 / 95$

h 309-822-8185 
APPENDIX C

Cover Letter to Participants 
Dear Oncology Nurse:

I am a graduate student in the nursing department at San Jose State University. I am conducting research to determine oncology nurses' attitudes toward the legalization of voluntary active euthanasia. Your participation will provide valuable data on the subject. There are no risks anticipated by participation in this study. You have been randomly selected from the oncology Nursing society members living in the West, namely in California, oregon, and washington.

You should understand that your participation is voluntary and that choosing not to participate in this study will not affect your relations with San Jose state University. The enclosed questionnaire takes approximately five minutes to complete. A demographic survey is also included. Your individual response will remain anonymous. All information will be reported as grouped data. The results of this study may be published, but any information that could result in your identification will remain confidential.

Please complete the questionnaire and return it in the self-addressed envelope. Return of the questionnaire will serve as informed consent. If you have any questions about this study, I will be happy to talk with you. I can be reached at (408) 866-5340. Questions or complaints about research, subjects' rights, or research-related injury may be presented to Serena Stanford, Ph.D., Associate Academic Vice President for Graduate Studies and Research, at (408) 924-2480.

Thank you for contributing to this study.

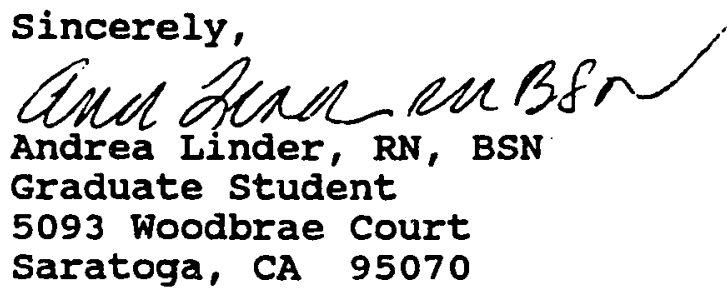

